\title{
EDUKASI PERILAKU HIDUP BERSIH DAN SEHAT (PHBS) PADA ANAK-ANAK DI KAMPUNG PEMEKARAN MISTER NGIOSI MANOKWARI PADA MASA PANDEMI COVID-19
}

\section{Education of Clean and Healthy living Behavior (PHBS) to children in Kampung Pemekaran Mister Ngiosi Manokwari during the Covid-19 Pandemic}

\author{
Sabarita Sinuraya, Elda I.J.J. Kawulur, Febriza Dwiranti, Rawati Panjaitan, Sita Ratnawati \\ Jurusan Biologi Fakultas Matematika dan Ilmu Pengetahuan Alam Universitas Papua
}

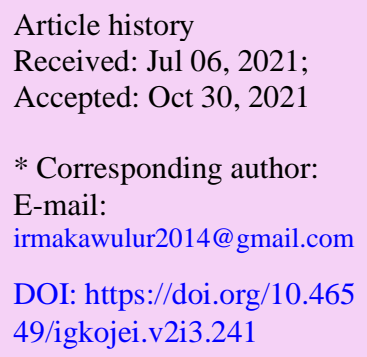

\begin{abstract}
Clean and Healthy Lifestyles are all health behaviors that are carried out consciously so that family or family members can help themselves in the health sector and play an active role in health-related activities in the community. This community service program is motivated by the limited access to information, transportation, and health services in rural areas of Kampung Pemekaran Mister Ngiosi Manokwari causing a lack of understanding and application of a clean and healthy lifestyle by children, especially during the Covid-19 pandemic. To overcome this gap, it is necessary to disseminate information about clean and healthy living behavior in children. Activities on PHBS were done through interactive learning in the form of lectures and answering questions related to the $P H B S$, providing rewards, and demonstrations regarding how to prevent the transmission of Covid-19. The results of the activity showed that about $80 \%$ of the children could carry out 11 steps of handwashing activity well. In terms of healthy food, $100 \%$ of the children finished the food provided.
\end{abstract}

Key words: Children; Clean and Healthy Lifestyle; Covid-19 Pandemic.

\begin{abstract}
ABSTRAK
Pola Hidup Bersih dan Sehat (PHBS) adalah semua perilaku kesehatan yang dilakukan atas kesadaran sehingga anggota keluarga atau keluarga dapat menolong dirinya sendiri di bidang kesehatan dan berperan aktif dalam kegiatankegiatan kesehatan di masyarakat. Program pengabdian pada masyarakat ini dilatarbelakangi oleh keterbatasan akses informasi, transportasi dan kesehatan di daerah pedesaan Kampung Pemekaran Mister Ngiosi Manokwari menyebabkan minimnya pemahaman dan penerapan pola hidup bersih dan sehat oleh anak-anak terutama pada pada pandemi Covid-19. Untuk mengatasi kesenjangan ini maka perlu dilakukan penanaman perilaku hidup bersih dan sehat pada anak-anak. Kegiatan penyuluhan tentang PHBS dilakukan dalam bentuk ceramah dan tanya jawab, pemberian reward, dan demonstrasi yang berkaitan dengan pencegahan penularan Covid-19. Hasil kegiatan menunjukkan bahwa dalam hal kegiatan 11 langkah mencuci tangan yang didemonstrasikan, sekitar $80 \%$ anak-anak dapat melaksanakannya dengan baik langkah-langkah tersebut. Dalam hal pemberian makanan sehat, $100 \%$ anak-anak menghabiskan makanan yang diberikan.
\end{abstract}

Kata kunci: Anak-anak; Pandemi covid-19; Perilaku Hidup Bersih dan Sehat. 


\section{PENDAHULUAN}

Pola Hidup Bersih dan Sehat (PHBS) adalah semua perilaku kesehatan yang dilakukan atas kesadaran sehingga anggota keluarga atau keluarga dapat menolong dirinya sendiri di bidang kesehatan dan berperan aktif dalam kegiatan-kegiatan kesehatan di masyarakat (Kemenkes 2009). Tujuan utama dari PHBS adalah meningkatkan kualitas kesehatan melalui proses penyadartahuan yang menjadi awal dari kontribusi individu-individu dalam menjalani perilaku kehidupan sehari-hari yang bersih dan sehat, sementara manfaatnya adalah meningkatkan kesadaran masyarakat untuk mau menjalankan hidup bersih dan sehat, agar masyarakat dapat mencegah dan menanggulangi masalah kesehatan (Kemenkes, 2016). Pola hidup bersih tidak hanya perlu dilakukan oleh orang dewasa, akan tetapi sejak usia dini seorang anak baik di sekolah maupun dalam keluarga perlu diajarkan dan dididik tentang pola hidup bersih dan sehat.

Selama masa Pandemi Covid-19, masyarakat termasuk anak-anak dituntut untuk meningkatkan kebersihan dan kesehatan pribadi dan lingkungan. Pandemi ini telah memberikan dampak luas dalam segala aspek kehidupan, termasuk pada anak-anak di daerah pedesaan yang memiliki keterbatasan akses kesehatan dan informasi. Selain itu, kebijakan work from home dalam upaya menanggulangi Virus Corona, menyebabkan kegiatan proses belajar mengajar di sekolah ditiadakan sehingga anakanak lebih banyak menghabiskan waktunya di rumah untuk beraktivitas termasuk belajar. Pemahaman dan informasi tentang perilaku hidup bersih dan sehat pada anak-anak tersebut perlu diajarkan secara bertahap dan berulang-ulang agar perilaku itu dapat terbentuk menjadi karakter sehingga kualitas hidup anak tersebut dapat ditingkatkan.

Penerapan 3M yaitu menjaga jarak, memakai masker, mencuci tangan yang benar yang dicanangkan pemerintah dalam upaya meminimalisir penyebaran Virus Corona juga peru diajarkan pada anak-anak sehingga kehidupan baru yang berorientasi pada kesehatan bersama dapat tercipta. Oleh karena itu edukasi yang menarik perlu dilakukan terhadap anak-anak prasekolah hingga orang dewasa agar pemahaman tentang perilaku hidup bersih dan sehat dapat diterima dengan baik dan diterapkan dalam kehidupan sehari-hari. Tujuan dari kegiatan pengabdian pada masyarakat ini adalah memberikan edukasi tentang cara hidup bersih dan sehat pada anak-anak di Kampung Pemekaran Mister Ngiosi Distrik Aimasi Kabupaten Manokwari.

\section{METODE}

Kegiatan pada masyarakat ini dilaksanakan pada hari Sabtu, 5 Juni 2021 bertempat di Kampung Pemekaran Mister Ngiosi Distrik Aimasi Manokwari. Peserta yang mengikuti kegiatan tersebut terdiri dari para mahasiswa dan dosen Jurusan Biologi FMIPA UNIPA berjumlah 15 orang dan anakanak kampung setempat sebanyak 26 anak. Pelaksanaan kegiatan dalam bentuk sosialisasi berupa penyuluhan dan praktik contoh (demostrasi) PHBS kepada anak-anak usia prasekolah, sekolah 
tingkat dasar dan sekolah tingkat menengah, serta pemberian paket pencegahan Covid-19 dan reward/hadiah.

Kegiatan penyuluhan tentang PHBS dilakukan dalam bentuk ceramah dan tanya jawab. Ceramah disampaikan menggunakan alat bantu infocus, laptop dan speaker. Ceramah dilakukan dalam bentuk pembelajaran interaktif disertai praktik. Praktik 10 langkah cuci tangan didemonstrasikan oleh mahasiswa kemudian diikuti oleh para peserta, sementara praktik senam didemonstrasikan oleh dosen diiringi oleh musik. Pada akhir ceramah dilakukan tanya jawab berkaitan dengan materi PHBS. Bagi peserta yang dapat menjawab pertanyaan yang disampaikan oleh tim pelaksana diberikan reward.

Kegiatan lain yang dilakukan adalah pemberian masker dan cairan antiseptik hand sanitizer sebagai upaya pencegahan penyebaran Virus Corona, dan praktik cara penggunaannya. Selain itu dilakukan pula pemberian paket sikat gigi dan odol terutama anak-anak usia dini dan pemberian makanan sehat berupa kacang hijau dan telur rebus.

\section{HASIL DAN PEMBAHASAN}

Anak-anak di Kampung Pemekaran Mister Ngiosi yang berjumlah sebanyak 26 orang beserta mahasiswa dan dosen Universitas Papua sebanyak 15 orang mengikuti seluruh kegiatan pengabdian dengan antusias dan semangat (Gambar 1). Adapun seluruh kegiatan yang dilakukan adalah kegiatan ceramah, kemudian dilanjutkan dengan demonstrasi, tanya jawab. Selain itu dilakukan pula kegiatan lain untuk melengkapi salah satu perilaku hidup sehat pada masa Covid ini adalah pembagian masker dan cairan antiseptik hand sanitizer, pemberian makanan bergizi, paket odol dan sikat gigi, serta praktek cara menggunakannya (Gambar 2,3).

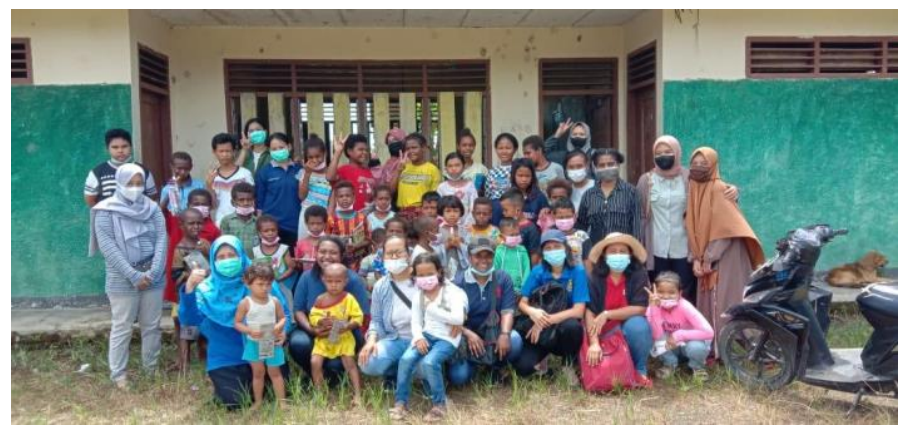

Gambar 1. Peserta dan Tim Pengabdian pada Masyarakat FMIPA UNIPA 


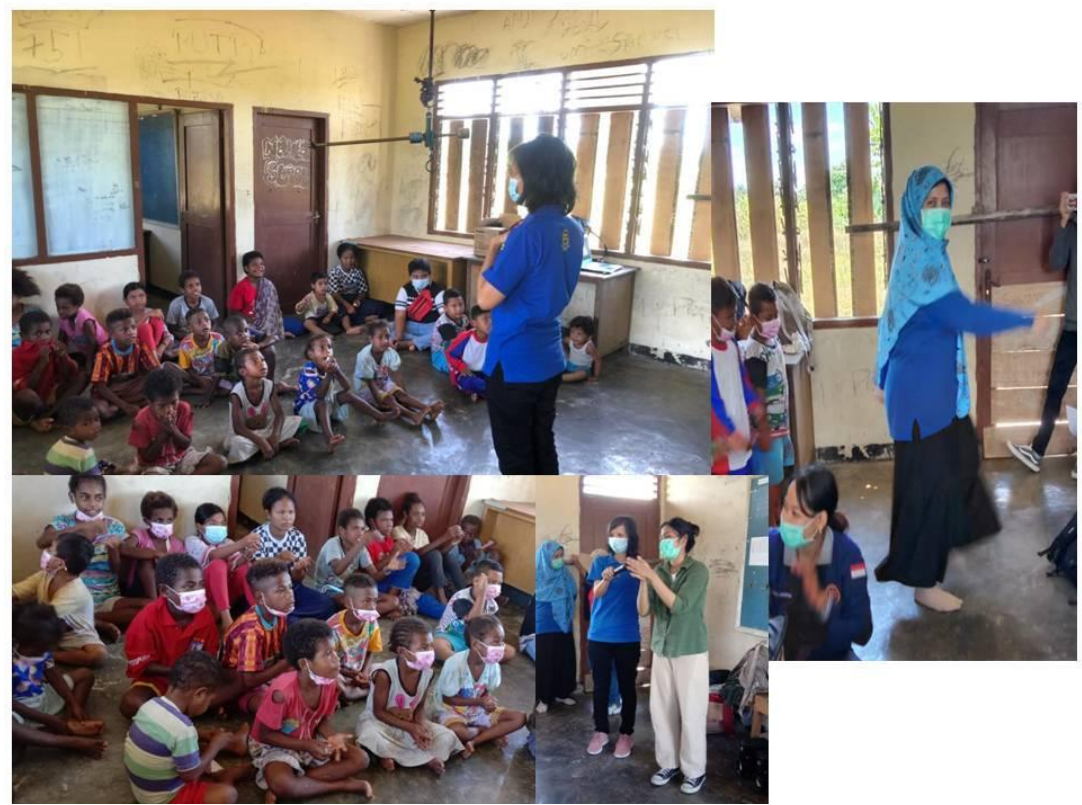

Gambar 2. Pelaksanaan kegiatan pengabdian pada masyarakat: ceramah (atas), praktik cuci tangan (bawah), praktik senam (kanan)

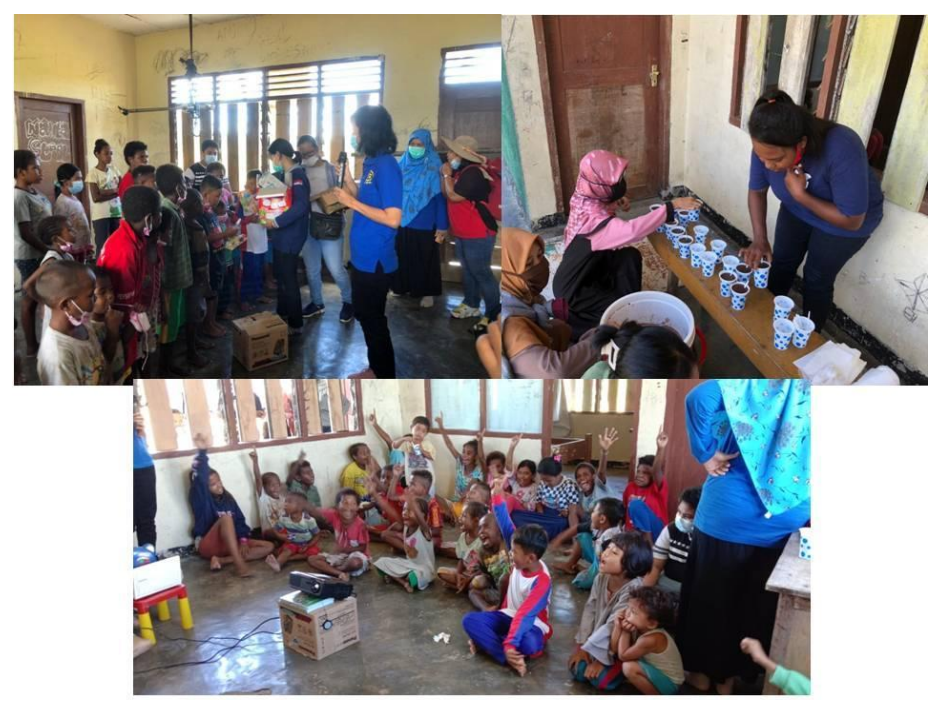

Gambar 3. Pelaksanaan Kegiatan Pengabdian pada Masyarakat: Pemberian sikat gigi dan odol (kiri), sarapan (kanan), dan sesi tanya jawab (bawah)

Kesadaran anak-anak tentang bahaya Virus corona masih sangat minim. Hal itu ditunjukkan oleh peserta yang hadir dalam kegiatan pengabdian tidak menggunakan masker. Demikian pula saat pembagian dan demonstrasi cara penggunaan masker dan hand sanitizer, sebagian besar anak-anak tidak tahu cara penggunaan masker dan hand sanitizer dan merasa tidak betah saat menggunakan masker tersebut (Gambar 4). 


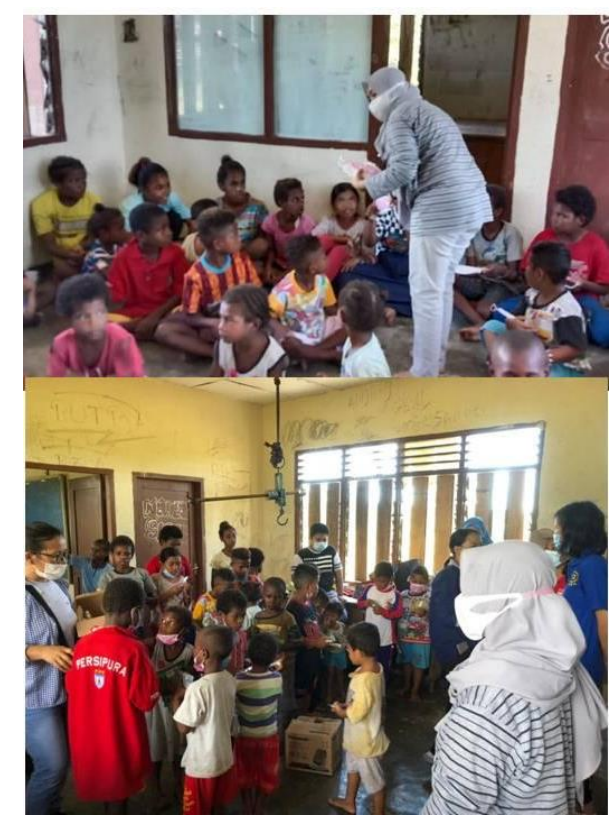

Gambar 4. Pemberian Masker (atas) dan Hand Sanitizer (bawah)

Demonstrasi 11 langkah cuci tangan yang didemonstrasikan mengacu pada panduan WHO (2009) dengan durasi sekitar 40-60 detik (Gambar 5). Pertama adalah membilas tangan dengan air, (2) menuangkan sabun di seluruh tangan, (3) menggosok pada kedua telapak tangan, (4) telapak tangan kanan di atas punggung tangan kiri dan sebaliknya dengan kedua jari saling terkait, (5) telapak dengan telapak dengan jari saling terkait, (6) punggung jari diletakkan pada telapak satunya dengan jari saling mengunci, (7) jempol kanan digosok memutar dengan telapak kiri, dan sebaliknya, (8) jari kiri menguncup, gosok memutar ke kanan dan ke kiri pada telapak tangan kanan, dan sebaliknya, (9) tangan dibilas dengan air, (10) mengeringkan tangan dengan handuk, (11) matikan kran dengan handuk.

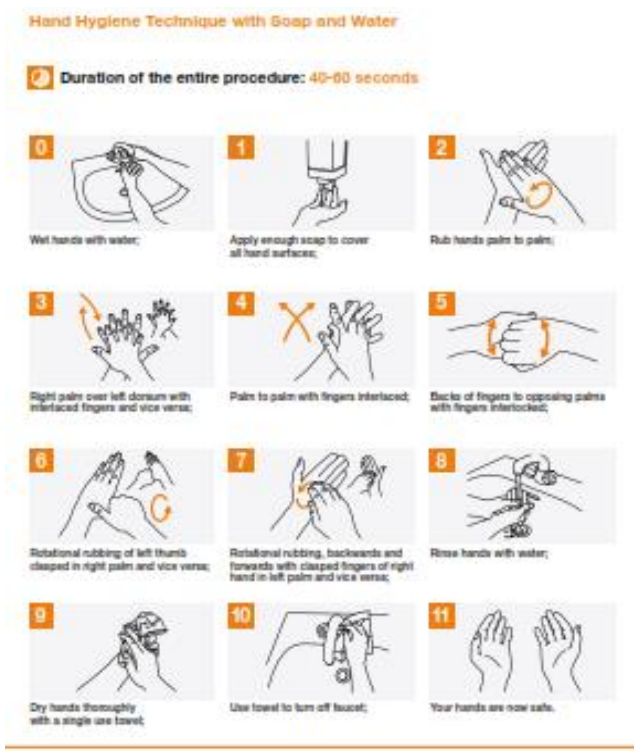

Gambar 5. Panduan mencuci tangan (WHO, 2009) 
Kegiatan mencuci tangan didemonstrasikan oleh seorang mahasiswa di depan anak-anak, kemudian anak-anak mempraktekkan secara langsung. Setelah diberi contoh 2 kali, kemudian anakanak diminta untuk mempraktikkan sendiri cara mencuci tangan tanpa panduan. Anak-anak yang dapat mempraktikkan secara benar diberikan reward. Berdasarkan pengamatan, $100 \%$ anak-anak dapat mencuci tangan dengan benar mengikuti demonstrasi yang diberikan, akan tetapi pada saat mempraktekkan sendiri, sekitar $80 \%$ anak-anak dapat mengikuti ke-11 langkah mencuci tangan walaupun tidak secara berurutan.

Kegiatan pemberian makanan sehat juga dilakukan dalam kegiatan pengabdian ini. Makanan yang diberikan berupa telur rebus dan kacang hijau. Berdasarkan pengamatan, $100 \%$ peserta menikmati makanan yang diberikan dan menghabiskannya. Praktik untuk menggosok gigi sebenarnya akan dilakukan setelah anak-anak mengkonsumsi makanan sehat, akan tetapi keterbatasan waktu dan air, maka praktik kegiatan tersebut tidak dilakukan. Paket odol dan sikat gigi yang dipersiapkan hanya dibagikan kepada anak-anak

Pola Hidup Bersih dan Sehat merupakan salah satu upaya pemerintah dalam meningkatkan taraf hidup masyarakat. Tatanan PHBS melibatkan beberapa elemen yang merupakan bagian dari tempat beraktivitas dalam kehidupan sehari-hari. Terdapat 5 tatanan PHBS yaitu PHBS di rumah tangga, sekolah, tempat kerja, sarana kesehatan, dan tempat umum (Kemenkes, 2016). Bagi anak-anak, beberapa indikator PHBS yang dicanangkan oleh Kementerian Kesehatan antara lain menyuci tangan dengan air yang mengalir dan memakai sabun, mengkonsumsi jajanan sehat di kantin sekolah, menggunakan jamban yang bersih dan sehat, olahraga yang teratur dan terukur, memberantas jentik nyamuk, tidak merokok di sekolah, menimbang berat badan dan mengukur tinggi badan setiap bulan, dan membuang sampah pada tempatnya.

Kondisi lokasi pedesaan yang jauh dari perkotaan kemungkinan menyebabkan akses untuk mendapat fasilitas kesehatan berupa masker dan hand sanitizer terbatas, sehingga walaupun semakin meningkat jumlah korban Covid-19 hal tersebut tidak menimbulkan kecemasan pada anak-anak sehingga kesadaran 3M tersebut belum diterapkan. Untuk menanamkan kesadaran anak untuk berperilaku hidup bersih dan sehat perlu kerja sama dari orang tua, guru dan masyarakat. Tugas yang yang diberikan oleh guru di sekolah tentang PHBS terutama bagi anak-anak sekolah usia dini seperti olahraga, cara mencuci tangan yang benar dan makan makanan bergizi dalam bentuk video, dipraktikkan oleh anak-anak dengan bantuan orang tua di rumah (Safitri \& Harun, 2021).

Program perilaku hidup bersih dan sehat yang dicanangkan oleh pemerintah perlu disosialisasikan kepada masyarakat luas, tidak hanya terbatas kepada anak-anak. Demikian halnya program pelatihan tentang PHBS perlu juga sosialisasi. Saat ini orang tua memiliki peranan penting dalam menciptakan PHBS di dalam keluarga, terutama pada masa Pademi Covid-19. Informasi yang berkaitan dengan anjuran pemerintah dalam mencegah penyebaran virus seperti saat bersin tutup 
mulut dengan siku dalam/masker, tidak boleh berkerumun, tidak memegang wajah dengan tangan kotor, perbanyak makanan bergizi dan istirahat yang cukup, sering cuci tangan, menghindari bersalaman dengan orang lain, bila sakit seperti flu dan demam melakukan isolasi mandiri perlu sampaikan dan diajarkan secara kontinyu sehingga tercipta budaya dan perilaku hidup sehat.

Anhusadar \& Islamiyah, 2021 melakukan penelitian pada orang tua tentang pemahaman dan penerapan PHBS pada anak-anak pada masa Pandemi Covid, menunjukkan bahwa orang tua telah paham dengan PHBS bahkan telah mendapatkan pelatihan PHBS sebanyak 56,9\%. Selain itu informasi PHBS dalam upaya mencegah penyebaran virus diperoleh juga melalui youtube, membaca berita secara online, mengakses berita-berita yang ada pada website gugus tugas penanganan Covid. Kemudahan dalam mengakses informasi secara online yang digambarkan oleh Anhusadar \&Islamiyah (2021) berbeda dengan kondisi yang dihadapi oleh masyarakat di Kampung Pemekaran Mister Ngiosi yaitu keterbatasan jaringan internet sehingga mereka kesulitan dan terbatas dalam mengakses berita dan berkomunikasi secara online. Oleh karena program sosialisasi dan penyuluhan tatap muka secara langsung perlu secara kontinyu dilaksanakan terutama pada daerah pedesaan yang memiliki keterbatasan akses kesehatan dan komunikasi.

Penelitian Wati (2020) menemukan bahwa pengetahuan dan sikap masyarakat tentang PHBS cenderung cukup baik dan positif, akan tetapi penerapannya dalam kehidupan sehari-hari masih kurang. Kondisi ini kemungkinan ditemui pula pada kebanyakan masyarakat. Oleh karena itu program pelatihan dan penyuluhan perlu dilakukan secara kontinyu. Selain itu kader PHBS di masing-masing kampung perlu dibentuk yang akan memonitoring dan mengevaluasi berbagai program pemerintah terkait PHBS agar dapat diterapkan dengan baik dan tepat sasaran.

\section{KESIMPULAN}

Penyuluhan tentang Perilaku Hidup Bersih dan Sehat pada anak-anak di Kampung Pemekaran Mister Ngiosi Manokwari mendapatkan respon positif. Keberlanjutan program PHBS melalui sosialisasi dan pelatihan kepada orang tua dan juga masyarakat secara umum di Kampung tersebut perlu dilakukan secara kontinyu. Pelibatan puskesmas atau tenaga kesehatan, kader2 dalam pelatihan dan sosialisasi tentang PHBS perlu dilakukan.

\section{UCAPAN TERIMA KASIH}

Ucapan terima kasih disampaikan kepada Kepala Kampung Pemekaran Mister Ngiosi atas izin dan fasilitas yang disediakan untuk menunjang pelaksanaan kegiatan, Parita Wahyudi, Vionita Putri atas bantuan dalam proses surat menyurat, persiapan materi dan tempat kegiatan.

\section{DAFTAR PUSTAKA}

Anhusadar, L. dan Islamiyah, I. 2021. Penerapan Perilaku Hidup Bersih dan Sehat Anak Usia Dini di 
Tengah Pandemi Covid 19. Jurnal Obsesi : Jurnal Pendidikan Anak Usia Dini, 5(1), pp. 463475. doi: 10.31004/obsesi.v5i1.555.

Kementerian Kesehatan Direktorat Promosi Kesehatan dan Pemberdayaan Masyarakat. 2016 Perilaku Hidup Bersih dan Sehat. PHBS kemkes.go.id (Accessed: 21 Desember 2020).

Kementerian Kesehatan Direktorat Promosi Kesehatan dan Pemberdayaan Masyarakat. 2012. Perilaku Hidup Bersih dan Sehat di Sekolah. https://promkes.kemkes.go.id/?p=1642 (Accessed: 21 Juni 2021).

Rahmawati, M. C. dan Dewi, N. D. L. 2019. Penanaman perilaku hidup bersih dan sehat di PAUD Atmabrata, Cilincing, Jakarta'. Jurnal Pemberdayaan Masyarakat, 3(1), pp. 42-49.

Wati, P. D. C. A. and Ridlo, I. A. 2020. Perilaku Hidup Bersih dan Sehat pada Masyarakat di Kelurahan Rangkah Kota Surabaya', Jurnal Promkes: The Indonesian Journal of Health Promotion and Health Education, 8(1), pp. 47-58. doi: 10.20473/jpk.v8.i1.2020.47-58.

Pittet, D. 2009. WHO Guidelines on Hand Hygiene in Health Care : A Summary First Global Patient Safety Challenge Clean Care is Safer Care, World Health Organization. Switzerland: World Health Organization can be obtained from WHO Press. Available at: http://whqlibdoc.who.int/publications/2009/9789241597906_eng.pdf. 